\title{
TRANSFORMASI MITE "MISTERI GANG KERAMAT" MENJADI NASKAH DRAMA SEBAGAI BAHAN AJAR BAHASA INDONESIA SISWA KELAS VIII SMP MUHAMMADIYAH 05 MEDAN TAHUN AJARAN 2019/2020
}

\author{
Nisa Prima Sari ${ }^{1}$, Ceni Rahim ${ }^{2}$, Ronald Wibowo Sitompul ${ }^{3}$, Sri Dinanta Beru Ginting ${ }^{4}$ \\ Universitas Prima Indonesia ${ }^{1}$, Universitas Prima Indonesia ${ }^{2}$, Universitas Prima Indonesia ${ }^{3}$, \\ Universitas Prima Indonesia ${ }^{4}$ \\ Pos-el: nisaprima2908@gmail.com ${ }^{1}$, cenirahim64@gmail.com², \\ ronaldwibowo386@gmail.com ${ }^{3}$, sridinantaginting@unprimdn.ac.id ${ }^{4}$
}

\begin{abstract}
ABSTRAK
Penelitian ini diangkat untuk mentransformasikan mite "Misteri Gang Keramat" menjadi naskah drama dan dijadikan sebagai bahan ajar Bahasa Indonesia pada siswa SMP kelas VIII SMP Muhammdiyah 05 Medan. Penelitian ini menggunakan metode penelitian deskriptif kualitatif bertujuan untuk mendeskripsikan secara sistematis, faktual, dan akurat dengan menggunakan kata-kata atau kalimat. Penelitian ini dilaksanakan mulai bulan November 2018 sampai dengan Oktober 2019. Teknik pengumpulan data menggunakan teknik simak bebas libat cakap. Data dalam penelitian ini adalah data lisan berupa mite "Misteri Gang Keramat". Sumber data dalam penelitian ini adalah informan dari masyarakat Gang Keramat, Mabar, Medan Deli. Teknik analisis data menggunakan analisis interaktif, yaitu reduksi, penyajian data, dan penarikan simpulan. Teknik validitas data menggunakan triangulasi metode dan sumber. Prosedur penelitian meliputi perencanaan, pelaksanaan, dan peyusunan laporan. Hasil penelitian diketahui mite "Misteri Gang Keramat" ini terbentuk karena adanya unsur mistis di daerah tersebut, terdapat sebuah pohon yang dianggap keramat dan sering didatangi oleh masyarakat sekitar untuk meminta sesuatu. Tujuan masyarakat bermacam-macam, ada yang meminta kesembuhan, keberuntungan dan sebagainya. Jika permintaan atau permohonannya terkabul, maka para penduduk sekitar akan meletakkan sesajen di bawah pohon sebagai wujud syukur. Sehingga dahulu para orang tua mengingatkan anaknya untuk tidak keluar malam karena daerah tersebut merupakan keramat, dari situlah mite ini muncul. Mite yang telah disusun kemudian ditransformasikan oleh peneliti menjadi naskah drama untuk dijadikan sebagai bahan ajar Bahasa Indonesia.
\end{abstract}

Kata Kunci: Transformasi, Mite “Misteri Gang Keramat”, Naskah Drama.

\section{ABSTRACT}

This research was appointed to transform the "Sacred Gang Mystery" myth into a drama script and was used as an Indonesian language teaching material for class VIII junior high school students of SMP Muhammadiyah 05 Medan. This study uses descriptive qualitative research methods aimed at describing systematically, factually, and accurately by using words or sentences. This research was conducted from November 2018 to October 2019. The technique of collecting data uses proficient free listening techniques. The data in this study are oral data in the form of a myth "Sacred Gang Mystery". The data sources in this study were informants from the Gang Keramat community, Mabar, Medan Deli. Data analysis techniques use interactive analysis, namely reduction, presentation of data, and drawing conclusions. The data validity technique uses triangulation methods and sources. Research procedures include planning, implementing, and compiling reports. The results of the study revealed the myth "Sacred Gang Mystery" was formed because of the mystical elements in the area, there is a tree 
that is considered sacred and often visited by surrounding communities to ask for something. The purpose of the community is varied, some ask for healing, luck and so on. If the request or request is granted, then the surrounding residents will place offerings under the tree as a form of gratitude. So that in the past parents reminded their children not to go out at night because the area was sacred, that's where the myth appeared. Mite that has been compiled is then transformed by researchers into drama scripts to be used as teaching materials for Indonesian.

\section{Keywords: Transformation, Mite "Sacred Gang Mystery", Drama Script.}

\section{PENDAHULUAN}

Karya sastra pada dasarnya sebagai kreativitas seseorang terhadap ide, pikiran, dan perasaan yang dimilikinya. Karya sastra merupakan hasil imajinasi manusia yang mengambil kehidupan manusia sebagai sumber inspirasinya. Karya sastra tidak mungkin lahir dari kekosongan budaya.

Hakikat karya sastra adalah rekaan atau yang lebih sering disebut imajinasi. Imajinasi dalam karya sastra adalah imajinasi yang berdasarkan kenyataan. Imajinasi tersebut juga diimajinasikan oleh orang lain. Menurut Ratna (2005: 312), hakikat karya sastra adalah rekaan, karya sastra dikonstruksi atas dasar kenyataan.

Sastra juga tidak terlepas dari persoalan kesusastraan daerah, khususnya cerita rakyat yang ada pada masing-masing daerah. Cerita rakyat membantu masyarakat untuk mengenal dan mengetahui tradisi kebudayaan yang dimilikinya, baik di daerahnya maupun di daerah lain yang telah diwariskan secara turun-temurun sehingga dapat diapresiasikan dikehidupan sekarang maupun yang akan datang.

Sekalipun karya sastra hanya berupa imajinasi yang menjadikan kehidupan manusia sebagai objek kajiannya, sastra juga memiliki fungsi sosial dalam menumbuhkan nilai dan karakter bagi pembacanya. Oleh sebab itu, sastra perlu dipelajari sebagai salah satu bahan bacaan dalam dunia pendidikan dan pengetahuan lain sebagai pembentukan sikap dan moral penerus bangsa.
Dalam karya sastra terdapat mite, yaitu salah satu jenis dari karya sastra yang artinya cerita suatu bangsa tentang dewa atau pahlawan zaman dahulu, yang mengandung penafsiran tentang asal usul semesta alam, manusia, dan bangsa itu sendiri yang mengandung arti mendalam yang diungkapkan dengan cara gaib.

Berdasarkan hal tersebut, dapat disimpulkan oleh peneliti bahwa mite adalah suatu cerita rakyat yang isinya benar-benar dianggap suci serta kisahnya pernah terjadi pada zaman dahulu, yang umumnya ceritanya bersifat gaib.

Mite yang ada di Sumatera Utara tidak sepopuler mite yang ada di Pulau Jawa hal ini disebabkan semakin rendahnya kecintaan masyarakat khususnya peserta didik terhadap cerita rakyat yang ada di Sumatera Utara. Satu diantara mite di Sumatera Utara yang perlu diangkat dan dikaji adalah mite "Misteri Gang Keramat" dari Desa Mabar, Medan Deli, Sumatera Utara. Selanjutnya, diketahui terdapat peninggalan situs sebagai bukti adanya mite tersebut pada masa lampau.

Berdasarkan informasi yang diperoleh peneliti ketika melakukan observasi awal, bahwa situs tersebut berasal dari peninggalan pohon keramat yang berada di dalam Gang Keramat tersebut. Beringin rindang itu disebut keramat karena bisa mengabulkan banyak permohonan masyarakat sekitar. Baik sebagai penyembuh, meminta keberuntungan, keselamatan dan lain sebagainya. Tidak sedikit pula masyarakat yang meletakkan nasi kuning di bawah pohon tersebut sebagai wujud 
syukur mereka karena permohonannya dikabulkan.

Bertitik tolak dari informasi itu, perlu dilakukan penelitian lebih lanjut mengenai mite "Misteri Gang Keramat". Hal ini disebabkan karena peserta didik belum mengetahui dengan jelas bagaimana cerita rakyat atau mite "Misteri Gang Keramat", maka peneliti akan mentransformasikan mite ini ke dalam bentuk naskah drama. Transformasian mite tersebut menjadi naskah drama bertujuan agar peserta didik dapat mengetahui dan menggambarkan bagaimana mite tersebut. Mitos (mite) adalah cerita prosa rakyat yang dianggap benar-benar terjadi setelah dianggap suci oleh empunya. Mite ditokohkan oleh dewa atau makhluk setengah dewa. Peristiwanya terjadi di dunia lain atau bukan di dunia yang seperti kita kenal sekarang ini dan terjadi di masa lampau

Rahmanto (1998: 66), menatakan bahwa drama merupakan bentuk karya sastra yang sulit dibanding dengan bentuk sastra lain. Dikatakan sulit karena untuk dapat menciptakan naskah drama yang baik seseorang harus melalui latihan terus-menerus. Dalam menulis naskah drama dibutuhkan juga kreativitas yang tinggi untuk dapat menghasilkan naskah drama yang menarik dan merangsang pembaca atau penikmat karya sastra.

Mite "Misteri Gang Keramat" ini juga dapat diubah dalam naskah drama melalui suatu pendekatan dengan tujuan agar penceritaan mite tersebut dapat diketahui secara jelas oleh siapapun yang membacanya. Menurut Nurgiyantoro (2007: 18), transformasi adalah perubahan suatu hal atau keadaan. Bentuk perubahan, ada kalanya berubah kata, kalimat, struktur, dan isi karya sastra itu sendiri. Selain itu transformasi juga bisa dikatakan, pemindahan atau pertukaran suatu bentuk ke bentuk lain, yang dapat menghilangkan, memindahkan, menambah, atau mengganti unsur.

Mite "Misteri Gang Keramat" yang akan ditransformasikan menjadi naskah drama akan menggambarkan jelas unsur dari cerita, seperti tokoh dan penokohan, alur, gaya bahasa, latar, sampai amanat akan tergambar dengan jelas. Pentransformasian dalam bentuk naskah drama diharapkan dapat menjadi cara penyebarluasan mite ini dengan cepat. Selain itu, hasil transformasi mite "Misteri Gang Keramat" perlu dijadikan bahan ajar agar cepat tersebar luas dan membuat masyarakat mengetahui bahwa di daerah Medan Deli, tepatnya di Desa Mabar terdapat suatu gang yang dinamai "Gang Keramat" karena dahulu terdapat pohon keramat yang menjadi pengabul permohonan masyarakat sekitar.

Atas dasar mite "Misteri Gang Keramat" dan mentransformasikannya menjadi naskah drama sebagai bahan ajar dalam mata pelajaran Bahasa Indonesia, maka peneliti berkeinginan mengkaji secara fokus mite tersebut dengan mengangkat judul "Transformasi Mite "Misteri Gang Keramat" Menjadi Naskah Drama Sebagai Bahan Ajar Bahasa Indonesia Siswa Kelas VIII SMP Muhammadiyah 05 Medan Tahun Ajaran 2019/2020".

Masyarakat pada umumnya belum mengetahui dengan jelas bagaimana cerita rakyat atau mite "Misteri Gang Keramat", maka penulis akan mentransformasikan mite ini ke dalam naskah drama agar masyarakat benar-benar dapat mengetahui bagaimana asal usul mite tersebut. Semua unsur akan tergambar jelas melalui naskah drama tersebut, seperti tokoh dan penokohan, alur, gaya bahasa, latar sampai amanat akan tergambar dengan jelas. Menurut Kristeva (1980: 66), pentransformasian ini dikaji melalui pendekatan intertekstualitas, yaitu adanya hubungan antara suatu teks dengan teks lain dimana setiap teks 
merupakan penyerapan dan transformasi dari teks-teks lain.

Transformasi dilakukan dengan melihat hubungan intertekstual dalam teks yang kita kaji, hubungan intertekstual antara teks dengan hipogram atau teks dasarnya dapat berupa ekspansi, modifikasi, konversi dan ekserp (Sardjono dalam Pudentia, 1992). Pentransformasian dalam bentuk naskah drama diharapkan dapat menjadi cara penyebarluasan mite ini dengan cepat. Penelitian yang akan dilaksanakan ini adalah tindak lanjut dari penelitian mengenai cerita rakyat berupa mite "Misteri Gang Keramat". Agar naskah drama tersebut menjadi naskah drama yang baik dan dapat dijadikan bahan ajar, maka dibutuhkan beberapa teknik dalam penulisannya, yaitu: a. menentukan tema; b. menentukan alur cerita; c. menyusun adegan dan $d$. membuat dialog tokoh.

Mite yang diangkat peneliti ini menceritakan tentang pohon yang keramat dimana terdapat sosok gaib yang dianggap mulia dan dapat mengabulkan beberapa permintaan masyarakat sekitar. Adapun hal-hal yang berkaitan dengan Transformasi mite "Misteri Gang Keramat", adalah bentuk mite "Misteri Gang Keramat", transformasi mite "Misteri Gang Keramat"menjadi naskah drama dan mendokumentasikan mite "Misteri Gang Keramat"dan transformasinya menjadi naskah drama dalam bentuk bahan ajar Bahasa Indonesia.

Penelitian mite "Misteri Gang Keramat" termasuk cerita yang belum dipulikasi. Untuk melanjuti penelitian tersebut, peneliti tetap konsisten mengenai sastra, khususnya sastra daerah yang harus dikembangkan dan dipublikasikan. Hal tersebut sejalan dengan bidang yang digeluti peneliti, yaitu mahasiswa/i Program Studi Bahasa dan Sastra Indonesia.

Penelitian ini dilakukan untuk mengetahui bagaimana bentuk mite
"Misteri Gang Keramat" yang diuraikan oleh masyarakat Mabar dan untuk mengetahui bagaimana cara mentransformasi mite "Misteri Gang Keramat" menjadi naskah drama yang selanjutnya akan dijadikan sebagai bahan ajar pada siswa kelas VIII SMP.

Berdasarkan hal tersebut, masalah yang muncul sangat luas. Untuk itu, peneliti membatasi pokok permasalahan pada "Transformasi Mite "Misteri Gang Keramat" Menjadi Naskah Drama Sebagai Bahan Ajar Bahasa Indonesia Siswa Kelas VIII SMP Muhammadiyah 05 Medan Tahun Ajaran 2019/2020" yaitu pada bentuk mite "Misteri Gang Keramat" dan cara mentransformasikan mite "Misteri Gang Keramat" menjadi naskah drama.

\section{METODE PENELITIAN}

Penelitian ini menggunakan metode penelitian deskriptif kualitatif. Penggunan metode ini bertujuan untuk meneliti suatu objek secara alamiah yang dideskripsikan secara akurat dan sistematis. Semua datanya diuraikan sesuai dengan kenyataan yang ditemukan di lapangan saat penelitian (Moleong, 2007: 209). Berdasarkan data dan sumber data yang dibutuhkan dalam penelitian maka penelitian ini tergolong dalam penelitian deskriptif karena peneliti terlibat langsung ke lapangan untuk mengumpulkan data yang dibutuhkan dalam penelitian.

Lokasi penelitian dilakukan di Gang Keramat, Desa Mabar, Kec. Medan Deli, Sumatera Utara. Penentuan lokasi penelitian ini karena menjadi asal dari mite Gang Keramat. Lama waktu penelitian berlangsung selama satu tahun yakni mulai November 2018 - Oktober 2019.

Data dalam penelitian ini berupa data lisan berupa mite Gang Keramat yang terdapat di masyarakat Mabar berdasarakan bentuk, fungsi, dan maknanya. Sumber data di dalam penelitian ini adalah informan dari 
masyarakat sekitar Gang Keramat (Mabar). Sedangkan sumber data tersebut selanjutnya dicatat dari informan yang menuturkannya. Informan yang dimaksud dalam penelitian ini adalah para orang tua yang sudah lama bermukim didaerah Mabar dan masyarakat sekitar Gang Keramat.

Berdasarkan sumber data tersebut, metode yang digunakan dalam pengumpulan data yaitu metode simak. Menurut Sudaryanto (1993:132), metode simak ialah metode yang digunakan dalam penelitian bahasa dengan cara menyimak penggunaan bahasa pada subjek yang diteliti.

Setelah pengumpulan data, selanjutnya untuk menganalisis diperlukan teknik analisis data agar analisis data dapat dilakukan dengan tepat. Berdasarkan hal tersebut, teknik analisis data dalam penelitian ini menggunakan teknik analisis interaktif. Langkah-langkah analisis data menurut Miles dan Huberman (1992:15-19), adalah pengumpulan data, reduksi data, penyajian data dan penarikan kesimpulan.

Pada tahap pengumplan data dilakukan dengan observasi, wawancara dan dokumentasi dengan menentukan strategi pengumpulan data yang dipandang tepat dan untuk menentukan fokus serta pendalaman data pada proses pengumpulan data berikutnya. Instrumen dalam pengumpulan data yaitu berupa daftar pertanyaan yang digunakan untuk mewawancarai informan dan peralatan yang digunakan untuk mendokumentasikan hasil penelitian. Pengumpulan data digunakan untuk bisa memfokuskan hasil agar lebih akurat.

Selanjutnya pada tahap reduksi data adanya kegiatan pemilihan, pemusatan, penyederhanaan, dan pengabstrakan data yang diperoleh dari sumber data penelitian. Dalam tahap ini, data yang diperoleh dicatat dalam uraian yang terperinci. Dari data yang dicatat tersebut dilakukan penyederhanaan data dengan cara membuang data yang tidak mendukung atau tidak berkaitan dengan masalah yang dianalisis. Kaitannya dengan penelitian ini, data yang dipilih berkaitan dengan bentuk mite "Misteri Gang Keramat" di Mabar, Medan Deli.

Pada penyajian data diperoleh berbagai jenis, jaringan kerja, keterkaitan kegiatan atau table serta rangkaian organisasi informasi yang memungkinkan penelitian dilakukan. Data tersebut dianalisis sehingga diperoleh deskripsi mengenai bentuk mite "Misteri Gang Keramat" .

Dan setelah penyajian data, harus ada tahap penarikan kesimpulan dari data yang telah diperoleh sejak awal penelitian. Akan tetapi, kesimpulan yang diperoleh adalah kesimpulan yang bersifat sementara berkaitan dengan mite "Misteri Gang Keramat" yang setelah selesai disimpulkan akan diuji keabsahannya. Setelah mite terbentuk maka hasil penelitian tersebut disusun sebagai bahan ajar pada mata pelajaran Bahasa Indonesia pada siswa SMP kelas VIII.

Selanjutnya adalah mengecek keabsahan atau teknik validitas data, dimana validitas data merupakan "derajat ketetapan antara data yang terjadi pada objek penelitian dengan daya yang dapat dilaporkan oleh peneliti". Teknik validitas data dapat dilakukan melalui teknik triangulasi (Sugiyono, 2006: 207). Trianggulasi merupakan teknik pemeriksaan keabsahan data dengan memanfaatkan sesuatu yang lain diluar data itu untuk keperluan pengecekan data atau sebagai pembanding terhadap data itu.

Berdasarkan hal tersebut, peneliti akan menguji keabsahan data dengan memberikan hasil bentuk mite "Misteri Gang Keramat" kepada para informan dan beberapa warga yang bermukim di Gang Keramat, dimana data yang didapat telah disusun sesuai dengan hasil penelitian berdasarkan observasi, wawancara dan dokumentasi. Setelah itu 
untuk memperoleh data yang valid atau data jenuh, peneliti juga mengolah data sesuai dengan hasil wawancara dengan informan untuk memvaliditaskan beberapa data sehingga terbentuk mite "Misteri Gang Keramat".

Prosedur penelitian merupakan penjelasan langkah-langkah yang harus ditempuh dalam suatu penelitian. Hal tersebut karena melalui prosedur penelitian yang telah direncanakan terlebih dahulu, kegiatan penelitian dapat terkontrol dengan baik.

Dimulai dengan tahap perencanaan yaitu kegiatan menyusun perumusan masalah, penyusunan rancangan penelitian dan menentukan cara dalam pengumpulan data. Berkaitan dengan uraian sebelumnya, di dalam penelitian ini, terdapat dua rumusan masalah yang disusun, yaitu bagaimana bentuk mite "Misteri Gang Keramat" yang diuraikan oleh masyarakat sekitar Gang Keramat, Mabar dan bagaimana cara mentransformasikan mite "Misteri Gang Keramat" menjadi naskah drama yang akan digunakan sebagai bahan ajar pada siswa.

Selanjutnya pada tahap pelaksanaan meliputi pengumpulan data, pengelompokkan data, analisis data dan interpretasi data. Tahap pengumpulan data, peneliti melalui dua tahap, yaitu mengumpulkan data dari informan untuk memperoleh mite Misteri Gang Keramat secara lengkap. Tahap pengelompokkan adalah tahap peneliti mengelompokkan data yang diperoleh berdasarkan rumusan masalah di dalam penelitian ini. Tahap selanjutnya adalah tahap analisis data dari hasil wawancara. Tahap terakhir adalah interpretasi data yang berupa jawaban dari rumusan masalah yang telah diketahui.

Tahap penyusunan laporan menjadi tahap terakhir dalam prosedur penelitian. Tahap ini dilakukan peneliti setalah semua data yang dibutuhkan telah terkumpul, telah direduksi, telah dianalisis dan telah disimpulkan. Tahap ini adalah tahap memindahkan hasil penelitian yang diperoleh ke dalam bentuk laporan yang bersifat ilmiah.

\section{HASIL DAN PEMBAHASAN Hasil Penelitian}

Pada umumnya mite yang berkembang di Indonesia memiliki kekhasan dan nilai masing-masing. Mite yang diangkat peneliti adalah mite yang sama sekali belum pernah dibukukan atau dipublikasi, hanya berupa cerita masyarakat dari mulut ke mulut yang biasa disebut sastra lisan. Data yang didapat untuk disusun menjadi sebuah mite ini yaitu hasil dari wawancara beberapa informan yang bermukim di lokasi penelitian, tepatnya di Gang Keramat, Mabar, Medan Deli, Sumatera Utara.

Mite ini didapat oleh peneliti dari pengumpulan, analisis dan validitas data secara menyeluruh sehingga terbentuklah mite "Misteri Gang Keramat" ini yang telah diuji keabsahan datanya oleh peneliti kepada informan dan penduduk sekitar Gang Keramat. Dalam mengumpulkan data agar membentuk mite, peneliti membuat daftar pertanyaan untuk dijawab oleh informan (subjek penelitian). Dimana terdapat kategorisasi dalam mewawancarai informan, antara lain adalah:

\section{Tabel 1}

Kategorisasi pertanyaan melalui instrumen wawancara

\begin{tabular}{|l|ll|}
\hline 1. & $\begin{array}{l}\text { Kebenaran } \\
\text { adanya mite } \\
\text { "Misteri Gang } \\
\text { Keramat" }\end{array}$ & $\begin{array}{l}\text { Keadaan } \\
\text { pohon yang } \\
\text { terdapat di } \\
\text { Gang }\end{array}$ \\
& $\begin{array}{l}\text { Keramat } \\
\text { hingga saat } \\
\text { ini }\end{array}$ \\
\hline 2. Alasan gang & 8. & $\begin{array}{l}\text { Keadaan } \\
\text { masyarakat } \\
\text { tersebut } \\
\text { dianggap } \\
\text { keramat }\end{array}$ \\
& $\begin{array}{l}\text { terhadap } \\
\text { keberadaan } \\
\text { pohon }\end{array}$ \\
\hline
\end{tabular}




\begin{tabular}{|c|c|}
\hline & keramat \\
\hline $\begin{array}{l}\text { 3. Alasan pohon } \\
\text { yang terdapat } \\
\text { di gang } \\
\text { tersebut } \\
\text { dianggap } \\
\text { keramat } \\
\end{array}$ & $\begin{array}{l}\text { 9. Hal lain yang } \\
\text { menyebabka } \\
\mathrm{n} \text { pohon } \\
\text { tersebut } \\
\text { dianggap } \\
\text { keramat }\end{array}$ \\
\hline $\begin{array}{l}\text { 4. Bentuk dari } \\
\text { pohon yang } \\
\text { terdapat di } \\
\text { Gang Keramat }\end{array}$ & $\begin{array}{l}\text { 10. Tujuan } \\
\text { masyarakat } \\
\text { mendatangi } \\
\text { pohon dan } \\
\text { Gang } \\
\text { Keramat }\end{array}$ \\
\hline $\begin{array}{ll}\text { 5. } & \text { Pendapat } \\
\text { masyarakat } \\
\text { terhadap } \\
\text { pohon yang } \\
\text { terdapat di } \\
\text { Gang Keramat } \\
\text { tersebut }\end{array}$ & $\begin{array}{l}\text { 11. Hal mistis } \\
\text { lain tentang } \\
\text { Gang } \\
\text { Keramat }\end{array}$ \\
\hline $\begin{array}{l}\text { 6. Alasan } \\
\text { pemberian } \\
\text { nama gang } \\
\text { menjadi Gang } \\
\text { Keramat }\end{array}$ & $\begin{array}{l}\text { 12. Informan } \\
\text { menceritakan } \\
\text { kembali } \\
\text { mengenai } \\
\text { mite tersebut } \\
\text { sesuai } \\
\text { dengan } \\
\text { apersepsinya }\end{array}$ \\
\hline
\end{tabular}

\section{Berdasarkan}

kategorisasi

pertanyaan di atas, peneliti dapat menyimpulkan data yang dimana data berupa mite ini telah divaliditas oleh informan dan para penduduk sekitar Gang Mabar, adapun bentuk mite "Misteri Gang Keramat" adalah sebagai berikut :

\section{Mite "Misteri Gang Keramat"}

Alkisah di suatu daerah yang sekarang diberi nama Mabar, terdapat sebuah pohon beringin yang sering didatangi oleh penduduk setempat bahkan, penduduk yang berasal dari daerah lain dengan tujuan bermacammacam. Ada yang berkunjung dengan harapan sanak saudaranya dapat sembuh dari penyakit, meminta keberuntungan dan ada pula yang berkunjung untuk mendapat petunjuk mengenai angka togel yang akan keluar.

Konon pohon beringin tersebut memiliki tinggi lima meter dan tepat di bawah pohon tersebut terdapat batu apung seukuran guling yang biasanya menjadi tempat untuk meletakkan sesajen berupa makanan. Selain itu terdapat gundukan serupa bukit kecil di lokasi pohon beringin yang memanjang, apabila dilihat dari jauh terlihat seperti deretan kuburan. Ternyata gundukan tersebut memang dipercayai sebagai makam para pekerja paksa pada zaman Belanda.

Berbekal informasi dari tetangganya, berangkatlah seorang ibu sambil menggendong putra semata wayangnya yang sedang sakit keras untuk dibawa ke pohon beringin. Tidak lupa ibu tersebut membawa nasi urap sebagai nazar agar anaknya lekas sembuh. Ibu tersebut berjalan kaki dengan jarak yang lumayan jauh hingga tiba di jalan setapak yang menghubungkannya dengan pohon beringin. Di sekitar jalanan setapak masih ditumbuhi bambu liar dan sawahsawah milik penduduk sekitar.

Saat pohon beringin mulai terlihat, ibu tersebut mempercepat langkahnya sambil memeluk erat anaknya. Tiba digundukan tanah yang memiliki tinggi kira-kira satu meter, ibu tersebut berusaha memanjat, tapi terasa susah lantaran beban yang dibawanya terlampau berat. Hingga seorang juru kunci bernama Datuk Aning datang membantunya untuk naik ke atas gundukan.

Ketika tiba di pohon tersebut, ibu yang berumur tiga puluhan itu segera meletakkan nasi urap di atas batu apung di bawah pohon lalu meminta kepada Datuk Aning untuk membantunya memohon kepada pohon beringin tersebut agar menyembuhkan anaknya dari sakit yang berkepanjangan itu. 
Sontak Datuk Aning menganggukan kepalanya, tidak menunggu lama Datuk Aning langsung memulai ritual di bawah pohon agar si anak diharapkan sembuh dari penyakitnya.

Setelah ritual pembacaan doa sesuai tradisi adat jawa yang dilakukan Datuk Aning, ibu tersebut disuruh pulang dan banyak berdoa semoga anaknya cepat pulih. Selang waktu tiga hari, ternyata permintaan ibu tersebut kepada pohon beringin itu membuahkan hasil, anaknya yang dahulunya sakitsakitan serta lemah tak berdaya mulai menampakkan hasil. Tubuh si anak terlihat segar bugar dan ceria.

Sebagai ucapan rasa syukur, ibu tersebut membawa anaknya kembali datang ke pohon beringin dengan membawa nasi urap yang jumlahnya cukup untuk seluruh penduduk yang tinggal di daerah pohon beringin tersebut. Ternyata saat itu kebetulan hari Jum'at di mana nasi kuning dan ayam panggang selalu dihidangkan para penduduk sekitar sebagai syarat. Ibu tersebut baru tahu informasi itu dari salah satu penduduk sekitar, tak lama datanglah seluruh penduduk untuk makan bersama di bawah pohon beringin.

Ada juga warga yang memberitahu kepada ibu tersebut bahwa pada malam Jum'at biasanya akan terlihat keris yang mengeluarkan sinar bak kembang api yang melayang-layang dari jalan setapak menuju pohon beringin, ibu tersebut hanya tersenyum. Sebelum mendengar itu dari para warga, ia telah mendengar cerita anaknya juga mengenai sosok yang berada di pohon keramat itu, sosok kakek tua yang wajahnya berseri, sosok yang dipercayai telah membantu dalam menyembuhkan anaknya.

Tradisi itu berjalanan hingga puluhan tahun. Sekitar tahun 90-an daerah tersebut diberi nama Mabar dan telah banyak penduduk baru yang membangun rumah ditanah bekas tanaman bambu liar. Para tetua yang telah lama tinggal di tempat tersebut juga memperingatkan agar jangan membuat kegaduhan, karena dapat berdampak pada pohon beringin yang suasananya tiba-tiba menjadi seram. Selain itu, para tetua juga sering menakut-nakuti anak-anak agar tidak keluar dimalam hari di jalan setapak itu dengan alasan adanya pohon keramat yang menyeramkan. Hal tersebut menyebabkan jalan setapak yang dahulu dilalui oleh orang untuk datang ke pohon beringin keramat itu diberi nama Gang Keramat.

Lalu, di tahun 90-an lokasi sekitar pohon keramat dibeli oleh sebuah perusahaan minyak. Pohon beringin yang tadinya kokoh ditebang setengah oleh pihak perusahaan, kemudian di jadikan Pekong untuk ibadah umat Buddha. Namun begitu, sampai saat ini para warga Mabar tetap mengingat bahwa pernah ada keajaiban pada pohon beringin keramat yang sangat membantu kelangsungan hidup mereka dulu sehingga kekeramatan itu tetap terasa bagi orang-orang yang pernah merasakan langsung keajaibannya yang pernah ada pada Gang Keramat di daerah Mabar, Medan Deli, Sumatera Utara. (Cerita diperoleh dari informan di Gang Keramat, Mabar, Medan Deli, Sumatera Utara).

Mentransformasikan mite menjadi naskah drama dapat dikaji melalui pendekatan intertekstualitas. Intertekstualitas adalah adanya hubungan antara suatu teks dengan teks lain dimana setiap teks merupakan penyerapan dan transformasi dari teksteks lain. Mite "Misteri Gang Keramat" yang akan ditransformasikan menjadi naskah drama akan menggambarkan jelas unsur dari cerita, seperti tokoh dan penokohan, alur, gaya bahasa, latar, sampai amanat akan tergambar dengan jelas. Adapun hasil transformasi mite "Misteri Gang Keramat" menjadi naskah drama adalah sebagai berikut: 


\section{Naskah Drama "Misteri Gang} Keramat"

PELAKON:
1. Mbok Asih
2. Bima
3. Sumi
4. Tini
5. Datuk Aning
6. Suryo

Alkisah di suatu kampung terdapat sebuah pohon beringin yang sering didatangi oleh penduduk dengan tujuan bermacam-macam; ada yang berkunjung dengan harapan sanaksaudara dapat sembuh dari penyakit, ada yang meminta rezeki dan sebagainya. Mendengar cerita yang berkembang tersebut berangkatkah Mbok Asih sambil menggedong putra semata wayangnya bernama Bima yang telah lama menderita sakit keras untuk dibawa ke pohon beringin. Saat di pertengan jalan, Mbok Asih berpapasan dengan dua orang warga kampung.

\section{(Adegan 1)}

Mbok Asih : “ (tersenyum menyapa dua warga kampung) permisi, saya mau tanya. Apakah pohon beringin yang terkenal itu sudah dekat dari sini?"

(Dua orang warga kampung saling bertatapan kebingungan)

Tini : "Pohon beringin yang mana, toh? (menyeggol bahu Sumi)"

Sumi : "Mungkin maksud Mbok ini pohon keramat!"

Mbok Asih : "Iya, pohon itu. Apakah pohon beringin yang katanya keramat itu memang dapat menyembuhkan penyakit?"
Sumi

: "Pohon keramat memang terkenal dapat membantu orang yang sedang kesusahan. Memangnya siapa yang sedang sakit Mbok?"

Mbok Asih : "'(menunduk sedih) anak saya di gendongan ini. Sudah berbulan-bulan dia sakit, tetapi belum sembuh juga dan tidak tahu apa penyebab sakitnya."

(Sumi dan Tini saling menatap sedih)

Tini

: "Siapa nama anaknya Mbok?" (menepuk pelan kepala Bima di gendongan Mbok Asih)

Mbok Asih : "Namanya Bima, bulan depan usianya genap lima tahun."

Sumi : "Oh, begitu. Saya doa kan semoga Bima cepat sembuh."

Tini : "Aamiin."

Sumi : "Pohon beringin masih lumayan jauh dari sini. Mbok masih harus berjalan kaki dengan jarak yang lumayan jauh hingga tiba di jalan setapak yang menghubungkan dengan pohon beringin. Di sekitar jalanan setapak itu banyak ditumbuhi bambu liar Mbok, ada juga sawahsawah milik penduduk sekitar. Mbok jalannya pelan-pelan saja yang penting bisa selamat sampai tujuan."

Mbok Asih : "Terima kasih atas pemberitahuannya, kalau begitu saya permisi dulu."

Mbok Asih terus berjalan dengan tertatih-tatih, tenaganya hampir habis karena perjalanan menuju pohon keramat cukup jauh dari rumahnya. Kelamaan pohon keramat mulai terlihat, Mbok Asih mempercepat langkahnya 
sambil memeluk erat anaknya. Dan disana erdapat gundukan yang memiliki tinggi kira-kira satu meter, Mbok Asih berusaha untuk melewati, tapi terasa susah lantaran beban yang dibaawanya terlampau berat. Hingga seorang juru kunci bernama Datuk Aning datang membantunya untuk naik ke atas gundukan tersebut.

Mbok Asih : "Terima kasih atas bantuannya, Pak."

Datuk Aning : "Sama-sama, panggil saja saya Datuk Aning."

(Mbok Asih tercengang)

Mendadak Mbok asih terduduk di tanah, perasaan haru membanjirinya karena bisa bertemu dengan Datuk Aning, seorang juru kunci pohon keramat.

Mbok Asih : "Tolong sembuhkan anak saya!” (Mbok Asih menangis).

Datuk Aning : "Saya tidak bisa menyembuhkan anak ibu"

Mbok Asih : "Kalau begitu bantulah saya untuk memohon kepada pohon beringin ini supaya Bima cepat sembuh."

Datuk Aning : "Jika begitu baiklah.

Datuk Aning melakukan ritual pembacaan doa berdasarkan pada tradisi turun-temurun suku jawa yang diamini oleh Mbok Aih yang duduk di belakangnya.

Datuk Aning : "Saya harap setelah ini Mbok meminta pada Tuhan agar Bima cepat sembuh. Biar bagaimanapun pohon ini hanya media kita untuk memohon kepada Tuhan, sebab hanya Tuhan lah yang pantas untuk kita sembah." (Datuk Aning mengusap kepala Bima)

Mbok Asih : "Terima kasih banyak Datuk Aning."

\section{(Adegan 2)}

Beberapa hari kemudian. Mbok Asih sedang menanak nasi, tiba-tiba Bima memanggil Mbok Asih dengan suara ceria.

Bima

: "Mbok?"

Mbok Asih : "Bima" (Mbok tergopoh-gopoh menuju kamar)

Bima : "Saya mau makan mbok."

Mbok Asih : "Kamu sudah sehat, nak? Sebentar lagi nasinya matang, sabar ya nak." (Mbok Asih menangis bahagia).

Mbok Asih : "Akhirnya kamu sembuh."

Bima : "Saya sembuh Mbok."

(Mbok Asih memeluk Bima)

Bima : "Sewaktu saya Mbok ajak ke pohon besar itu, di sana saya melihat seorang kakek berbaju putih, bercelana putih, dan berambut putih, semuanya putih dan terlihat bersinar seperti lampu. Kakek itu tersenyum pada saya Mbok. Kemudian tadi saya bertemu lagi kakek itu di dalam mimpi, beliau berkata bahwa saya anak yang baik, jadi saya akan sembuh supaya tidak membuat Mbok makin sedih."

Mbok Asih tercenung, seingatnya beberapa hari lalu pakaian yang dikenakan Datuk Aning berwarna hitam, bukannya putih seperti yang dikatakan Bima.

Mbok Asih : "Kalau begitu besok kita datang lagi ke pohon keramat itu, kamu mau kan Bima?"

Bima : "Mau Mbok, saya ingin bertemu dengan kakek itu lagi." 


\section{(Adegan 3)}

Berangkatlah Mbok Asih dan Bima dengan berbekal membawa nasi urap sebagai rasa syukurnya karena anaknya yang telah sembuh, Mbok Asih membawa nasi urap dengan jumlah yang cukup untuk seluruh penduduk yang tinggal di daerah pohon beringin tersebut. Ternyata saat itu merupakan hari Jum'at dimana nasi kuning dan ayam panggang juga selalu dihidangkan sebagai syarat untuk melakukan ritual do'a.

Mbok Asih : "Ada apa ini?" (tanya Mbok Asih bingung).

Suryo : 'Setiap hari Jum'at memang ramai begini Mbok. Warga di kampung ini selalu mengadakan ritual do'a untuk mengucapkan terima kasih sekaligus permohonan keselamatan"

Mbok Asih : :Bapak bukan penduduk sini?"

Suryo

: "Bukan. Saya dari kampung seberang. Saya datang karena kepengin kecipratan keberuntungan juga, soalnya saya ini orang susah, saya berharap semoga kehidupan saya bisa baik kedepannya."

Suryo : "Kalau Mbok ini asalnya dari mana?"

Mbok Asih : "Saya juga bukan dari kampung ini, kampung saya lumayan jauh dari sini."

Suryo : "Mau meminta permohonan juga?" (suryo terlihat penasaran.)

Mbok Asih : "Bukan. Justru saya ingin mengucapkan syukur karena akhirnya anak saya sembuh."

Tiba-tiba Datung Aning datang menghampiri kedua orang yang sedang bercengkerama tersebut. Beliau melihat Bima tampak sehat dan sedang bermain bersama anak-anak lainnya.

Datuk Aning : "Waaah... akhirnya bima sehat." (Datuk Aning tersenyum)

Mbok Asih : "Iya, Datuk. Saya sangat bahagia saat tahu Bima kini sehat dan ceria. Saya ingin mengucapkan teriam kasih, dan sebagai rasa syukur saya membawa nasi urap ini."

Datuk Aning : "Letakkan saja di atas batu, Mbok."

Mbok Asih segera meletakkan nasi urap di atas batu, berdampingan dengan nasi kuning dan ayam bakar.

Mbok Asih : "Semua ini berkat pohon keramat dan Datuk Aning."

Datuk Aning : "Bukan Mbok. Semua berkat Tuhan Yang Maha Esa karena telah memberikan kesempatan untuk kembuhan anak Mbok, pohon ini hanya media dan saya hanyalah manusia biasa yang memohon pada Tuhan."

Mbok Asih : "(mengangguk setuju)"

Mbok Asih : "Datuk, semalam anak saya bercerita bahwa dia bertemu dengan seorang kakek berpakaian seba putih dan tersenyum pada Bima."

Datuk Aning : "(tersenyum)"

Bima : "Mbok tadi saya bertemu lagi dengan kakek itu (Bima menghampiri tiba-tiba)."

(Datuk Aning masih tersenyum sambil berjalan menuju pohon keramat).

Datuk Aning : "Ayo ikut ritual pembacaan doa."

Berdasarkan hasil pentransformasian mite dalam bentuk naskah drama diharapkan dapat menjadi 
cara penyebarluasan mite ini dengan cepat. Berdasarkan langkah atau teknik penulisan naskah drama, maka dapat diklasifikasikan sebagai berikut:

\section{Menentukan tema}

Tema yang diangkat dalam naskah drama ini tentunya sesuai dengan tema atau topik yang terdeskripsi pada mite "Misteri Gang Keramat". Dimana temanya ialah keramat. Dalam naskah drama ini akan terdeskripsi jelas bahwa temanya keramat, karena pohon dan gang (jalan setapak) yang diceritakan mengandung unsur mistis. Selain dapat menyembuhkan penyakit, pohon yang berada di gang tersebut juga dapat mendatangkan keberuntungan. Jadi berdasarkan hal tersebut, para penduduk terdahulu memuja serta memohon pada pohon keramat itu agar keinginannya dikabulkan.

2. Menentukan alur cerita

Alur cerita pada naskah drama hasil transformasi dari mite "Misteri Gang Keramat" ialah menggunakan alur maju dan memiliki lima jenis tahapan cerita yang dapat dideskripsikan sebagai berikut :

a. Eksposisi

$$
\text { (pengenalan) }
$$

Pada bagian ini, pengarang akan memperkenalkan tokoh utama, penataan adegan cerita dan hubungan antar tokoh yang terdapat dalam cerita. Dimana eksposisi dalam drama ini adalah saat pertemuan Mbok Asih dengan Tini dan Sumi yang merupakan penduduk sekitar Gang Keramat, dimana Mbok Asih sambil menggedong putra semata wayangnya bernama Bima yang telah lama menderita sakit keras untuk dibawa ke pohon yang dianggap keramat.

b. Komplikasi

(pengenalan masalah)

Pada bagian ini pengarang atau pembuat cerita akan memunculkan bagian-bagian dalam cerita yang dapat menimbulkan permasalahan. Komplikasi pada drama ini adalah saat Mbok Asih terduduk di tanah, perasaan haru membanjirinya karena bisa bertemu dengan Datuk Aning, seorang juru kunci pohon keramat yang bisa membantunya dalam melakukan ritual penyembuhan anaknya.

$\begin{array}{lr}\text { c. Klimaks } & \text { (puncak } \\ \text { masalah) } & \\ \text { Pada bagian ini } \\ \text { merupakan } & \text { puncak } \\ \text { permasalahan } & \text { yang }\end{array}$ dihadapi oleh tokoh, pada bagian ini juga tokoh dalam cerita akan dihadapkan dalam penentuan akhir yang akan dialaminya, keberhasilan atau kegagalan biasanya menjadi penentuan nasib tokoh dalam cerita. Klimaks pada drama ini adalah saat Datuk Aning melakukan ritual pembacaan doa berdasarkan pada tradisi turun-temurun suku jawa untuk menyembuhkan anak Mbok Asih. Dimana akan ada sosok yang membantu orang-orang dalam meminta agar dikabulkan permohonannya.

d. Resolusi (penurunan) 
Resolusi ialah tahap penurunan konflik atau masalah yang terjadi, dimana resolusi pada drama ini ialah saat Mbok Asih tidak menyangka anaknya bisa sembuh dan segar bugar karena pohon keramat itu. Dan Bima, anaknya Mbok Asih menceritakan hal yang tidak dapat dilihat dengan kasat mata, yaitu sosok kakek tua yang dianggap sebagai penunggu pohon tersebut. Sosok itulah yang telah berbaik hati untuk menyembuhkannya.

\section{e. Penyelesain}

Bagian ini akan menjelaskan bagaimana nasib tokoh dalam cerita tersebut apakah endingnya bahagia, buruk, ataupun menggantung. Dimana penyelesaiannya adalah saat Mbok Asih datang kembali dan membawa nasi urap sebagai wujud syukurnya pada pohon tersebut, begitu pula para masyarakat sekitar yang memang sudah menjadikan tradisi menaruh sesajen pada pohon berupa nasi kuning dan ayam bakar sebagai wujud syukur terhadap pohon tersebut.

3. Menyusun adegan

Adegan adalah bagian babak. Satu babak terdiri dari beberapa adegan. Pada sebuah adegan akan tergambar satu suasana. Dimana pada naskah drama yang dibuat ini akan ada tiga adengan. Adegan pertama, saat kedatangan Mbok Asih di pohon keramat dan datangnya Datuk Aning untuk membantu jalannnya ritual. Adegan kedua, saat Bima, anaknya Mbok Asih yang didapati sudah sembuh dan segar bugar setelah dilakukannya ritual penyembuhan di pohon keramat. Dan adegan ketiga, saat kedatangan kembali Mbok Asih ke pohon keramat sebagai wujud syukurnya atas kesembuhan Bima dengan membawa nasi urap. Begitu juga para penduduk lain yang berbondong-bondong datang untuk meletakkan sesajen di pohon keramat tersebut.

4. Membuat dialog antar tokoh

Tokoh yang ada pada drama ini berjumlah enam orang. Selain efektiv dalam penggambaran karakter tokoh, pemilihan tokoh yang tidak terlalu banyak ini agar naskah yang dibaca mudah dipahami oleh pembaca.

\section{Pembahasan}

Mite merupakan salah satu jenis cerita rakyat yang berhubungan dengan kepercayaan manusia terhadap suatu benda. Berdasarkan hasil penelitian mite "Misteri Gang Keramat" ini terbentuk dari hasil observasi dan wawancara peneliti dengan informan yang sekaligus menjadi narasumber, sehingga akurasi dari bentuk mite ini bisa diuji langsung kepada para informan serta penduduk sekitar Gang Keramat, Mabar.

Dengan adanya kategorisasi yang ditanyakan kepada tiga informan melalui instrumen wawancara, peneliti menyususun dan menarik simpulan mengenai mite tersebut. Lalu dengan adanya pengumpulan, analisis dan validitas data maka terbentuklah mite "Misteri Gang Keramat" yang nantinya akan dijadikan sebagai bahan ajar Bahasa Indonesia siswa SMP kelas VIII SMP Muhammadiyah 05 Medan.

Penelitian ini sejalan dengan penelitian dari Sri Dinanta Beru Ginting pada tahun 2018 yang berjudul 
"Transformasi Cerita Rakyat Beru Ginting Ajinembah ". Penelitian ini bertujuan untuk menggali lebih dalam legenda ini secara lengkap melalui berbagai metode penelitian yang akan dilaksanakan. Hasil dari revitalisasi legenda "Beru Ginting Ajinembah atau Rumah Si Pitu Ruang" ini akan ditransformasi ke dalam bentuk naskah drama. Namun perbedaannya pada penelitian ini terletak pada jenis cerita rakyat atau objek yang diteliti, dimana pada artikel ini yang dijadikan objeknya ialah mite.

Penelitian relevan lainnya yaitu penelitian dari Sri Dinanta Beru Ginting dan Bambang Nur Alamsyah pada tahun 2018 yang berjudul "Eksplorasi Cerita Rakyat "Mehangke" Suku Karo Sebagai Bahan Ajar Kesusasteraan Di Prodi Pendidikan Bahasa Dan Sastra Indonesia Universitas Prima Indonesia". Penelitian ini bertujuan untuk mengangkat serta menggali kembali cerita "Mehangke" secara lengkap dan rinci melalui metode dan teknik analisis yang akurat. Selanjutnya setelah cerita rakyat tersebut digali maka ditemukanlah maksud serta nilai yang terkandung pada cerita tersebut yang selanjutnya akan dijadikan sebagai bahan ajar kesusasteraan pada Prodi Pendidikan Bahasa Dan Sastra Indonesia Universitas Prima Indonesia.

Berdasarkan penelitian-penelitian relevan tersebut, pentransformasian mite ini menjadi naskah drama diharapkan agar bisa menggambarkan secara jelas unsur dari cerita, seperti tokoh dan penokohan, alur, gaya bahasa, latar, sampai amanat serta dapat menjadi cara penyebarluasan mite ini dengan cepat. Seperti yang kita ketahui bentuk mite yang belum ditransformasikan hanya monoton pada bacaan yang terstruktur, sedangkan mite yang sudah ditransformasikan menjadi naskah drama akan mudah dipahami dan dimengerti siswa. Selain terdiri dari adegan, dialog antar tokoh dan penokohan karakter, naskah drama juga dilengkapi dengan prolog yang dapat membangun imajinasi dan ketertarikan siswa saat membaca naskah drama "Misteri Gang Keramat".

Hasil transformasi mite "Misteri Gang Keramat" menjadi naskah drama perlu dijadikan bahan ajar siswa SMP kelas VIII pada mata pelajaran Bahasa Indonesia, karena pendidikan merupakan wadah untuk menciptakan peserta didik sebagai penerus budaya bangsa ke masyarakat lebih luas lagi. Dengan demikian, penelitian ini juga dapat membuka wawasan peserta didik untuk lebih mengenal dan mencintai warisan leluhur khususnya mite.

Mite "Misteri Gang Keramat" yang telah ditransformasikan menjadi naskah drama ini selanjutnya akan diberikan kepada siswa SMP Kelas VIII SMP 05 Muhammdiyah Medan untuk dijadikan bahan ajar Bahasa Indonesia. Sebelum itu tentunya peneliti harus mewawancarai guru mata pelajaran Bahasa Indonesia di SMP Muhammadiyah 05 Medan untuk menunjukkan hasil mite dan naskah drama "Misteri Gang Keramat". Hal tersebut dimulai dengan pengenalan mite "Misteri Gang Keramat" disertai pemahaman terhadap unsur instrinsiknya. Selanjutnya mengenai langkah-langkah dalam mentransformasikan mite menjadi sebuah naskah drama yang sudah disusun peneliti. Dimana hal tersebut lebih efektif ketika digunakan sebagai publikasi dan pengembangan agar masyarakat luas, khususnya siswa lebih mengenal mite yang ada di daerahnya maupun daerah lain.

Menurut guru mata pelajaran Bahasa Indonesia di SMP Muhammadiyah 05 Medan mengenai mite dan naskah drama "Misteri Gang Keramat" yang telah disusun peneliti, telah relevan dan jelas sehingga pantas jika dijadikan bahan ajar Bahasa Indonesia pda siswa kelas VIII. Hal tersebut karena selaras dengan Silabus 
Bahasa Indonesia Kelas VIII K13 Revisi 2018 pada pembelajaran drama dan cerita rakyat. Selain itu, tingkat keterbacaan cerita yang dipaparkan pada mite atau naskah drama menurut guru telah jelas dan akan mudah dipahami siswa, berkaitan dengan penokohon, latar, alur dan gaya bahasanya juga menjadi elemen yang dikaji oleh guru mata pelajaran Bahasa Indonesia di SMP Muhammadiyah 05 Medan.

\section{SIMPULAN}

Berdasarkan hasil penelitian yang dipaparkan pada bab sebelumnya dapat disimpulkan bahwa mite dapat ditransformasikan menjadi naskah drama serta bisa dijadikan sebagai bahan ajar Bahasa Indonesia pada siswa SMP kelas VIII.

Mite "Misteri Gang Keramat" ini terbentuk karena pada zaman dahulu penamaan Gang Keramat diberikan sebab adanya unsur mistis di daerah tersebut, terdapat sebuah pohon yang dianggap keramat dan sering didatangi oleh masyarakat sekitar untuk meminta sesuatu. Tujuan masyarakat bermacammacam, ada yang meminta kesembuhan, keberuntungan dan sebagainya. Jika permintaan atau permohonannya terkabul, maka para penduduk sekitar akan meletakkan sesajen di bawah pohon sebagai wujud syukur. Konon unsur mistis kental sekali ,terlebih setiap malam Jum'at akan ada keris yang beterbangan menuju pohon keramat lalu malam Jum'at diyakini sebagai malam yang menakutkan. Sehingga dahulu para orang tua mengingatkan anaknya untuk tidak keluar malam karena daerah tersebut merupakan keramat, dari situlah mite ini muncul.

Mite "Misteri Gang Keramat" yang telah disusun peneliti berdasarkan akurasi dari para informan dan penduduk sekitar Gang Keramat, selanjutnya ditransformasikan menjadi naskah drama sesuai dengan teknik menyusun naskah drama yang benar. Tujuannya agar penggambaran unsur ceritanya lebih jelas dan menarik jika dijadikan bahan ajar Bahasa Indonesia pada siswa Kelas VIII SMP Muhammdiyah 05 Medan.

Berdasarkan hasil penelitian yang telah diperoleh, peneliti memberikan saran bahwa bahan ajar ini dapat menjadi masukan serta mengembangkan imajinasi dan ilmu pengetahuan dalam memahami bentuk mite dan cara mengubah suatu mite menjadi naskah drama melalui suatu pendekatan yang akan digunakan sebagai bahan ajar mata pelajaran Bahasa Indonesia. Selanjutnya dapat juga dijadikan sebagai bahan pengembangan wawasan mengenai cara mentransformasikan suatu mite menjadi naskah drama sesuai dengan teknik dan langkah yang benar

\section{DAFTAR PUSTAKA}

Kriteva, Julia. 1980. Desire in Language - A Semiotic Approach to Literature and Art. Oxford: Basil Blackwell

Miles, B. Mathew dan Michael Huberman. 1992. Analisis Data Kualitatif Buku Sumber Tentang Metode-Metode Baru. Jakarta: UIP.

Moleong, Lexy J. 2007. Metodologi Penelitian Kualitatif. Bandung: PT. Remaja Rosdakarya.

Nurgiyanto, Burhan. 2007. Teori Pengkajian Fiksi. Yogyakarta: Gajah Mada University Press.

Rahmanto, B, 1998. Metode Pengajaran Sastra. Yogyakarta: Kanisius.

Ratna, Nyoman Kutha. 2005. Teori, Metode dan Teknik Penelitian Sastra. Yogyakarta: Pustaka Belajar.

Sardjono, Partini. 1992. Pengantar Pengkajian Sastra. Bandung: Pustaka Wina. 
Sudaryanto. 1993. Metode dan Aneka

Teknis Analisis Bahasa.

Yogyakarta: Duta Wacana University Press.

Sugiyono. 2010. Metode Penelitian Kuantitatif dan $R \& D$. Bandung: Alfabeta. 